\title{
Ovarian cAMP and cGMP fluctuations in the hamster during the oestrous cycle
}

\author{
C. J. Hubbard* \\ Department of Anatomy, Bowman Gray School of Medicine, Wake Forest University, \\ Winston-Salem, North Carolina 27103, U.S.A.
}

\begin{abstract}
Summary. Cyclic GMP, cAMP and total DNA levels were determined in whole hamster ovaries on each day of the 4-day cycle. Pro-oestrous ovaries were removed during the time of the preovulatory LH surge (confirmed by RIA). Cyclic AMP levels (pmol/mg DNA) were highest during pro-oestrus $(1268.0 \pm 139$ (s.e.m.)) and lowest during dioestrus $2(266.9 \pm 22)$. Cyclic GMP (pmol/mg DNA) levels were highest at dioestrus $2(87.2 \pm 19)$ and lowest during oestrus $(11.9 \pm 2)$. Similar patterns were obtained with total $\mathrm{pmol} / 4$ ovaries. However expressed, there was an inverse correlation of CAMP and cGMP at dioestrus $2(P<0.02)$ and pro-oestrus $(P<0.001)$. Cyclic GMP was inversely correlated with total DNA levels $(P<0.02)$ at oestrus and dioestrus 2 .
\end{abstract}

\section{Introduction}

The action of cyclic nucleotides in ovarian function has focussed mainly on cAMP and the stimulatory effects of gonadotrophins (Fain \& Butcher, 1977). There is a significant increase in ovarian cAMP following a rise in endogenous LH in the immature rat pretreated with PMSG (Nilsson, Rosberg, Hillensjo \& Ahren, 1975). Both FSH and LH stimulate cAMP in granulosa cells in vitro (Lindsey \& Channing, 1979) and dibutryl cAMP initiates a number of gonadotrophin-associated activities such as steroidogenesis and luteinization (Channing \& Tsafriri, 1977).

The effects of gonadotrophins on ovarian cAMP and cGMP in vitro have been examined by Ratner (1976) and Makris \& Ryan (1978), but the results differed according to species and methods used. To date, cGMP and cAMP levels have not been examined in the normal animal nor is it clear what function cGMP may have in the ovary of the cyclic animal. The purpose of this study, therefore, was to examine both cAMP and cGMP levels in the whole ovary of the mature cyclic female hamster. The hamster was selected for this study because of the precise regularity of its oestrous cycle.

\section{Materials and Methods}

The hamsters (Mesocricetus auratus) used were virgins aged 60-90 days and weighing approximately $100 \mathrm{~g}$. They were kept in lighting conditions of $14 \mathrm{~h}$ light $(15: 00-05: 00 \mathrm{~h}) / 24 \mathrm{~h}$, and food and water were provided ad libitum. The period of oestrus was determined by placing a male in the female's cage and observing the lordosis response, as well as vaginal discharge. The animals were maintained for two cycles before use.

* Present address: Department of Physiology, MRRC-416, The University of Kansas Medical Center, 39th and Rainbow Boulevard, Kansas City, Kansas 66103, U.S.A. 
At least 8 animals were killed at 10:00 h on each day of the oestrous cycle (oestrus, dioestrus 1, dioestrus 2) except pro-oestrus, when they were killed at 02:00 h to correspond with the period of the pro-oestrous LH peak. Within 3-4 min of an i.p. injection of sodium pentobarbitone, both ovaries of 2 animals were removed, trimmed of fat and ground to a fine suspension in a ceramic mortar containing $2 \mathrm{ml} \mathrm{cold}\left(4^{\circ} \mathrm{C}\right) 5 \%$ trichloroacetic acid (TCA) and sand.

Cyclic nucleotides were extracted from the TCA suspension by washing 3 times with $1 \mathrm{ml}$ TCA. After extraction with anhydrous diethyl ether ( 3 washes, $20 \mathrm{ml}$ each) the final product was freeze dried. The dried extract was reconstituted with $2 \mathrm{ml}$ Tris-HCl buffer $(\mathrm{pH} \mathrm{7.5)}$ and assayed for cAMP and cGMP.

\section{DNA assay}

DNA was extracted from the pellet which remained after centrifugation of the TCA suspension, using $0.5 \mathrm{~N}$-perchloric acid and heat $\left(80^{\circ} \mathrm{C}\right.$ for $\left.20 \mathrm{~min}\right)$. DNA was measured by the colorimetric method of Burton (1956). Inter-assay variability was found to be $<7 \%$. Serial dilutions of test samples produced a linear curve over a 10 -fold range.

\section{Cyclic nucleotide assay}

The cAMP assay was performed using a commercially developed kit obtained from Diagnostic Products Co. (Los Angeles, California). The kit utilizes a [ ${ }^{3} \mathrm{H}$ ]cAMP competitive protein-binding assay based on the method of Gilman (1970), and modified by Tovey, Oldham \& Whelan (1974). Sensitivity of the assay was $1.1-27.0 \mathrm{pmol} /$ assay tube. Cross-reactivity (as measured at $50 \%\left[{ }^{3} \mathrm{H}\right]$ antigen displacement) with cGMP was $<0.1 \%$.

Cyclic GMP was measured using a radioimmunoassay kit (Amersham/Searle, Arlington Heights, Illinois) which utilized the procedures described by Steiner, Pagliari, Chase \& Kipnis (1972). Sensitivity of the assay was $0.5-8.0 \mathrm{pmol} /$ tube. Cross-reactivity of cAMP with cGMP at the $50 \%$ inhibition level required $10^{6} \mathrm{pmol} \mathrm{cAMP} /$ tube. Other nucleotides (GMP, GDP, GTP and ATP) were even less cross-reactive. Since cAMP was found in much higher concentrations than cGMP in the tissue samples, its cross-reactivity was further analysed by including samples of cAMP in a cGMP assay. A single concentration of cAMP was included in each assay tube (40 pmol/tube, twice that normally found in tissue samples) with cGMP standard curve concentrations. Interference was found to be $<1.0 \%$.

\section{LH assay}

Blood samples were collected at autopsy from all animals by vena cava puncture, allowed to clot and the serum removed and stored frozen for assay of LH. The radioimmunoassay was performed by a method similar to that of Niswender, Midgley, Monroe \& Reichert (1973) and which has been validated for the hamster by Blake, Norman \& Sawyer (1973). The LH used for standards and ${ }^{125}$ I labelling (LER-1056) was provided by Dr L. E. Reichert and LH antiserum was donated by Dr G. D. Niswender (Niswender \#6). Sensitivity was $1-256 \mathrm{ng} /$ tube.

The data from these assays were calculated using the logit-log method of linearization (Rodbard, 1974). Inter- and intra-assay variability was determined by the method of Rodbard (1974) for all radioimmunoassays and found to be $<7 \%$. Extraction efficiency was between 95 and $100 \%$ for both cyclic nucleotides. Serial dilutions of cAMP and cGMP samples gave linear values over a 20 -fold range. All samples were assayed in duplicate. The specificity of cAMP and cGMP assays was determined by incubating experimental samples containing known cyclic nucleotide concentrations with 0.026 i.u. cyclic nucleotide phosphodiesterase (Sigma Co., St. Louis, Missouri) in a $37^{\circ} \mathrm{C}$ water bath for $1 \mathrm{~h}$. When assayed, cGMP showed a $90 \%$ reduction 
in activity and cAMP concentrations decreased $90-100 \%$. These results, coupled with the fact that the two cyclic nucleotides fluctuated inversely, demonstrated the relative absence of non-specific substrate interference in the cyclic nucleotide assays by substances in the tissue extract.

The statistical analysis consisted of analysis of variance, the Newman-Keuls multiple range test, and the Pearson product-moment correlation test (Bruning \& Kintz, 1977). All values were expressed as means and standard error of the mean.

\section{Results}

The results in Table 1 show that cAMP remained stable throughout oestrus and dioestrus 1 with a slight but insignificant drop at dioestrus 2. The increase in cAMP at pro-oestrus coincided with an elevation in plasma LH. Cyclic GMP was lowest at oestrus and rose to the highest value during dioestrus 2 . When the two cyclic nucleotides were compared during dioestrus 2 and pro-oestrus, a significant inverse correlation was noted $(P<0.02 ; r=-0.5945)$.

Table 1. Ovarian cyclic nucleotide, DNA and serum LH changes during the hamster oestrous cycle

\begin{tabular}{|c|c|c|c|c|}
\hline & \multicolumn{4}{|c|}{ Stage of oestrous cycle } \\
\hline & Oestrus & Dioestrus 1 & Dioestrus 2 & Pro-oestrus \\
\hline $\begin{array}{l}\text { Conc. cAMP (pmol/mg DNA) } \\
\text { Conc. cGMP (pmol/mg DNA) }\end{array}$ & $\begin{array}{c}302 \cdot 1 \pm 40 \cdot 6^{\mathrm{a}} \\
11 \cdot 9 \pm 1 \cdot 5^{\mathrm{a}}\end{array}$ & $\begin{aligned} 309 \cdot 7 & \pm 35 \cdot 5^{\mathrm{a}} \\
51 \cdot 0 & \pm 5 \cdot 4\end{aligned}$ & $\begin{array}{r}217 \cdot 0 \pm 22 \cdot 3^{\mathrm{a}} \\
87 \cdot 3 \pm 14 \cdot 0^{\mathrm{b}}\end{array}$ & $\begin{aligned} 1268 \cdot 9 & \pm 138 \cdot 6^{b} \\
49.9 & \pm 6 \cdot 3\end{aligned}$ \\
\hline $\begin{array}{l}\text { Total cAMP (pmol } / 4 \text { ovaries) } \\
\text { Total cGMP (pmol/4 ovaries) }\end{array}$ & $\begin{array}{r}274 \cdot 5 \pm 35 \cdot 3 \\
10 \cdot 9 \pm 1.4^{\mathrm{a}}\end{array}$ & $\begin{aligned} 149 \cdot 5 & \pm 23 \cdot 6^{a} \\
27 \cdot 8 & \pm 3 \cdot 1\end{aligned}$ & $\begin{array}{l}87 \cdot 0 \pm 11 \cdot 0^{\mathrm{a}} \\
34 \cdot 3 \pm 3 \cdot 6^{\mathrm{b}}\end{array}$ & $\begin{array}{c}540 \cdot 0 \pm 23 \cdot 5^{b} \\
21 \cdot 7 \pm 3 \cdot 5\end{array}$ \\
\hline Total DNA (mg/4 ovaries) & $0.9 \pm 0.1^{b}$ & $0.5 \pm 0.1^{\mathrm{a}}$ & $0.4 \pm 0.1^{a}$ & $0.4 \pm 0.1^{2}$ \\
\hline Serum LH (ng/ml) & $7 \cdot 1 \pm 3 \cdot 0^{2}$ & $2 \cdot 2 \pm 0 \cdot 1^{a}$ & $1 \cdot 2 \pm 0.8^{a}$ & $193.8 \pm 72.6^{b}$ \\
\hline
\end{tabular}

Within rows, values with different superscripts are significantly different to at least $P<0.05$.

When values were expressed as totals in all 4 ovaries, cAMP was again highest at pro-oestrus and cGMP was highest at dioestrus 2. Total cAMP and cGMP levels were also inversely correlated during dioestrus and pro-oestrus $(P<0.001 ; r=-0.6232)$.

Total DNA was highest at oestrus. DNA levels showed a significant inverse correlation when compared with total CGMP at oestrus and dioestrus $(P<0.01 ; r=-0.624)$, but there was no such effect with cAMP.

\section{Discussion}

Ovarian cyclic AMP/mg DNA and total cAMP levels were highest during the pro-oestrous LH peak. Although it was not assayed, due to lack of facilities, FSH was also assumed to be high during this period as demonstrated by Bast \& Greenwald (1974) in the hamster. This increase in cAMP after gonadotrophin stimulation is similar to the results obtained in other studies (Marsh, 1976). A significant rise in cAMP has been observed in immature rat ovaries coincident with an endogenous LH surge stimulated by PMSG (Nilsson et al., 1975). Studies in vitro indicate that both FSH and LH are capable of stimulating cAMP in isolated rat follicles and quartered whole hamster ovaries during a 30-min incubation period (Ratner, 1976; Makris \& Ryan, 1978). In cyclic rats there is a 10 -fold increase in adenylate cyclase responsiveness to gonadotrophin stimulation between dioestrus and pro-oestrus which then declines following the gonadotrophin 
surge and desensitization (Hunzicker-Dunn \& Birnbaumer, 1976). LH and cAMP added to interstitial homogenates have been shown to cause a small increase in steroid production (Scoon \& Major, 1972).

Cyclic GMP showed an inverse relationship to both DNA and cAMP levels during dioestrus 2 and pro-oestrus (Table 1). Ratner (1976) also observed inverse changes in cGMP and cAMP in vitro when controls were compared to gonadotrophin-stimulated ovaries. These fluctuations occurred in ovaries containing well developed follicles following PMSG stimulation. Luteinized ovaries from rats injected with both PMSG and hCG showed only increases in cAMP and no change in cGMP following gonadotrophin exposure. Makris \& Ryan (1978) observed various responses to FSH or LH in hamster pro-oestrous follicles depending on the gonadotrophin used. These changes ranged from an increase in cAMP and no change in levels of cGMP when higher levels of LH were used (1.0 i.u./ml incubation medium) to decreases in cAMP and either no change or a transient increase in cGMP at lower $\mathbf{L H}$ concentrations $(0.005$ i.u. $/ \mathrm{ml})$. FSH, however, produced increases in cGMP at all doses and inverse fluctuations in cAMP at doses of 1.0 and $0.05 \mathrm{i} . \mathrm{u} . / \mathrm{ml}$. Although these data showed inverse correlations for the two cyclic nucleotides in the hamster, it is not known whether these events are truly linked in a 'Yin-Yang' fashion of the sort proposed by Goldberg et al. (1975).

Oestradiol has been reported to stimulate an increase in cGMP in immature rat uteri (Kuehl et al., 1974; Flandroy \& Galand, 1979). In the hamster, ovarian oestradiol levels rise markedly during dioestrus 2 (Saidapur \& Greenwald, 1978). It is possible, therefore, that the observed rise in ovarian cGMP during dioestrus 2 may in part be the result of oestradiol stimulation.

The changes in total DNA observed in this study are consistent with the $\left[{ }^{3} \mathrm{H}\right]$ thymidine studies of Sheela Rani \& Moudgal (1977) who showed primary incorporation during oestrus. Chiras \& Greenwald (1977) reported two peaks in $\left[{ }^{3} \mathrm{H}\right]$ thymidine incorporation which occurred during pro-oestrus and oestrus when FSH was elevated. The observed inverse correlation between CGMP and DNA during dioestrus 2 and oestrus may be due to luteolysis which occurs during this period (Leavitt, Basom, Bagwell \& Blaha, 1973) and, to a lesser extent, to follicular atresia (Greenwald, 1961).

From these results and the work of others, a working hypothesis may be formulated. Since morphological luteolysis during dioestrus 2 results in cell death, this could cause an increase in intracellular calcium influx (Farber \& El-Mofty, 1975), resulting in a cGMP increase (Wrenn, Currie \& Biddulph, 1978) and a decrease in detectable DNA levels. Other factors such as oestradiol may also be involved in the cGMP rise. Cyclic AMP, in turn, would increase during pro-oestrus in response to stimulation by FSH and LH.

Since this study was performed on whole ovaries, identification of the specific cell types involved cannot be made. Work is currently in progress, however, to examine the cyclic nucleotide, steroid and DNA changes in the various ovarian compartments of the cyclic hamster.

This work was supported by NIH Grant 5-R01-H006210 and was submitted in partial fulfilment for the Ph.D. degree of Wake Forest University.

\section{References}

Bast, J.D. \& Greenwald, G.S. (1974) Serum profiles of follicle stimulating hormone, luteinizing hormone and prolactin during the estrous cycle of the hamster. Endocrinology 94, 1295-1299.

Blake, C.A., Norman, R.L. \& Sawyer, C.H. (1973) Validation of an ovine-ovine LH radioimmunoassay for use in the hamster. Biol. Reprod. 8, 299-305.
Bruning, J.L. \& Kintz, B.L. (1977) Computational Handbook of Statistics, 2nd edn. Scott, Foresman and Co., Glenview, Illinois.

Burton, K. (1956) A study of the conditions and mechanism of the diphenylamine reaction for the colorimetric estimation of deoxyribonucleic acid. Biochem. J. 62, 315-322. 
Channing, C.P. \& Tsafriri, A. (1977) Mechanism of action of luteinizing hormone and follicle-stimulating hormone on the ovary in vitro. Metabolism 26, 413-468.

Chiras, D.D. \& Greenwald, G.S. (1977) An autoradiographic study of long-term follicular development in the cyclic hamster. Anat. Rec. 188, 331-337.

Fain, J.N. \& Butcher, F.R. (1977) Cyclic nucleotides in the mode of hormone action. In Review of Physiology, Endocrine Physiology, vol. II, pp. 241-294. Ed. S. M. McCann. University Park Press, Baltimore.

Farber, J.L. \& El-Mofty, S.K. (1975) The biochemical pathology of liver cell necrosis. Am. J. Path. 81, 237-250.

Flandroy, L. \& Galand, P. (1979) Oestrogen-induced increase in uterine cGMP content: a true hormonal action? Molec. cell. Endocr. 13, 281-290.

Gilman, A.G. (1970) A protein binding assay for adenosine $3^{\prime}: 5^{\prime}$ cyclic monophosphate. Proc. natn. Acad. Sci. U.S.A. 67, 305-312.

Goldberg, N.D., Haddox, M.K., Nicol, S.E., Glass, D.B., Sanford, C.H., Kuehl, F.A. \& Estensen, R. (1975) Biologic regulation through opposing influences of cyclic GMP and cyclic AMP: the Yin Yang hypothesis. Adv. cyclic Nuc. Res. 5, 307-330.

Greenwald, G.S. (1961) Quantitative study of follicular development in the ovary of the intact or unilaterally ovariectomized hamster. J. Reprod. Fert. 2, 351361.

Hunzicker-Dunn, M. \& Birnbaumer, L. (1976) Adenylyl cyclase activities in ovarian tissues. III. Regulation of responsiveness to $\mathrm{LH}, \mathrm{FSH}$ and $\mathrm{PGE}_{\mathrm{r}}$ in the prepubertal, cycling, pregnant and pseudopregnant rat. Endocrinology 99, 198-210.

Kuehl, F.A., Ham, E.A., Zanetti, M.E., Sanford, C.H., Nicol, S.E. \& Goldberg, N.D. (1974) Estrogenrelated increases in uterine guanosine $3^{\prime}, 5^{\prime}$ cyclic monophosphate levels. Proc. natn. Acad. Sci. U.S.A. 71, 1866-1870.

Leavitt, W.W., Basom, C.R., Bagwell, J.N. \& Blaha, C.C. (1973) Structure and function of the hamster corpus luteum during the estrous cycle. Am.J. Anat. 136, 235-241.

Lindsey, A.M. \& Channing, C.P. (1979) Influence of follicular maturation upon the effect of ovine follicle stimulating hormone and luteinizing hormone upon cyclic AMP accumulation by isolated porcine granulosa cells. Biol. Reprod. 20, 473-482.
Makris, A. \& Ryan, K.J. (1978) Cyclic AMP and cyclic GMP accumulation in hamster preovulatory follicles stimulated with LH and FSH. Acta endocr., Copenh. 87, 158-173.

Marsh, J. (1976) The role of cyclic AMP in gonadal steroidogenesis. Biol. Reprod. 14, 30-35.

Nilsson, L., Rosberg, S.M., Hillensjo, T. \& Ahren, K. (1975) Preovulatory changes of ovarian cyclic AMP in the rat. Life Sci. 16, 517-524.

Niswender, G.D., Midgley, A.R., Monroe, S.E. \& Reichert, L.E. (1973) Radioimmunoassay for rat luteinizing hormone with anti-ovine $\mathrm{LH}$ serum and ovine LH-I ${ }^{131}$. Endocrinology 128, 807-811.

Ratner, A. (1976) Effects of follicle stimulating hormone and luteinizing hormone upon cyclic AMP and cyclic GMP levels in rat ovaries in vitro. Endocrinology 99 , 1496-1500.

Rodbard, D. (1974) Statistical quality control and routine data processing for radioimmunoassays and immunoradiometric assays. Clin. Chem. 20, 12551270.

Saidapur, S.K. \& Greenwald, G.S. (1978) Peripheral blood and ovarian levels of sex steroids in the cyclic hamster. Biol. Reprod. 18, 401-408.

Scoon, V. \& Major, P. (1972) Regulation of steroid synthesis in rabbit ovarian homogenates by luteinizing hormone, cyclic AMP and pyridine nucleotides. J. Endocr. 52, 147-159.

Sheela Rani, C.S. \& Moudgal, N.R. (1977) Role of the pro-estrous surge of gonadotropins in the initiation of follicular maturation in the cyclic hamster: a study using antisera to follicle stimulating hormone and luteinizing hormone. Endocrinology 101, 14841494.

Steiner, A.L., Pagliari, A.S., Chase, L.R. \& Kipnis, D.M. (1972) Radioimmunoassay for cyclic nucleotides. II. Adenosine $3^{\prime}: 5^{\prime}$ cyclic monophosphate in mammalian tissues and body fluids. J. biol. Chem. 247, 1114-1119.

Tovey, K.C., Oldham, K.G. \& Whelan, J.A.M. (1974) A simple direct assay for cyclic AMP in plasma and other biological samples using an improved competitive protein binding technique. Clin. chim. Acta 56, $221-234$.

Wrenn, R.W., Currie, M.G. \& Biddulph, D.M. (1978) Influence of calcium, parathyroid hormone and ionophore A-23187 on cyclic nucleotide concentrations of isolated renal tubules. Molec. cell. Endocr. 10, 263-276. 